\title{
Age and the treatment of lung cancer
}

\author{
J S Brown, D Eraut, C Trask, A G Davison
}

\begin{abstract}
Background - The average age of patients with lung cancer is increasing and there are large numbers of elderly symptomatic patients with this common disease. However, there are few data on how the treatment of this group differs from that of younger patients.

Methods - From 1 January 1990 information was collected for the Southend Lung Cancer Registry on all patients with a diagnosis of lung cancer in a geographically well defined health district of the UK with a population of 325000 . Every effort was made to find new cases from all departments of the hospital, including all clinical diagnoses, histopathological and cytological reports, and necropsies. All death certificates in the district were examined, irrespective of age, for any diagnosis of lung cancer. This therefore included any patient not seen by the hospital services. The differences in initial treatment have been analysed for three age groups: under $65,65-74$ years, and over 75.
\end{abstract}

Results - The 563 cases of lung cancer diagnosed during a 30 month period were included in the study, of whom 240 (43\%) were aged over 75 years. The overall mean age was 71 years (range 31-95). The incidence of lung cancer in the general population was 69 per 100000 , but in men over 75 years of age it rose to 751 per 100000 . For all patients the active treatment rate (chemotherapy, surgery, or radiotherapy) was $49 \%$, but for patients not reviewed by a chest physician $(n=86)$ it was only $21 \%$. There were large differences in initial treatment between age groups. For patients with non-small cell lung cancer (NSCLC) reviewed by a chest physician, surgery was undertaken in $18 \%$ of those under $65,12 \%$ of the $65-74$ age group, and $2 \cdot 1 \%$ of those over 75 . For patients with small cell lung cancer (SCLC) reviewed by a chest physician, $79 \%$ of those aged under $65,64 \%$ of the $65-74$ age group, and $41 \%$ of patients aged over 75 received chemotherapy. In patients with NSCLC reviewed by a chest physician, chemotherapy was given to $21 \%$ under $65,6 \cdot 4 \%$ in the $65-74$ age group, and none over 75 . If no histological diagnosis was made $37 \%$ of patients aged under 75 and only $5 \cdot 4 \%$ of those over
75 received either surgery, radiotherapy, or chemotherapy. Patients not reviewed by a chest physician were less likely to have had a histological diagnosis. Differences in treatment rates with age persisted even after allowing for performance score status at presentation.

Conclusions - Lung cancer is a common disease in the elderly and, in our district, $43 \%$ of patients were aged 75 or over at presentation. Age alone appeared to be a major factor in influencing treatment choices, and treatment was more likely if histological confirmation was obtained. Further detailed analysis of the reasons for the differences is needed. Patients referred to chest physicians were more likely to have both histological confirmation and active treatment. This study supports the contention that all patients with a diagnosis of lung cancer, irrespective of age or condition, should be assessed by an accredited chest physician.

(Thorax 1996;51:564-568)

Keywords: lung cancer, age, treatment.

Lung cancer is the commonest cancer of adults in England and Wales and is increasingly common in women. ${ }^{12}$ The mean age of these patients is rising. ${ }^{3-5} \mathrm{~A}$ recent Royal College of Physicians report recommended that "all patients should have equal access to services and are not discriminated against because of their age". ${ }^{6}$ Most earlier studies of lung cancer have been surgical series or have been based on referrals to a chest physician or cancer treatment centre ${ }^{7-11}$ and elderly patients have probably been under represented. Mor et al found large differences in the treatment of cancer with age and concluded that "further research is needed, using an epidemiologically sound incident population, to begin to examine the factors that influence age related biases". ${ }^{12}$ If the treatment of the elderly patient differs from that of the younger patient, this has important implications for the provision of respiratory, geriatric, and oncological services and for the links between these disciplines. Using data from newly diagnosed patients with lung cancer in the Southend Health District, and making strenuous efforts to identify all patients, we have examined the differences in incidence and treatment in different age groups. 


\section{Methods}

From 1 January 1990 all patients with newly diagnosed lung cancer in the Southend Health District, a population of 325000 , have been entered into the Southend Lung Cancer Register. The district has the sea or rivers as its boundaries on three sides and there is very little movement of patients to other districts for diagnosis or treatment. There is only one histopathology and cytology service based at Southend Hospital. A diagnosis of lung cancer was accepted either on a positive histological or cytological report or if the patient had a combination of suggestive chest radiograph and clinical features. For patients with no histological confirmation of lung cancer the notes, radiographs, radioisotope and computed tomography scans were reviewed by one of the investigators $(\mathrm{DE})$ to ensure consistency and accuracy of the diagnosis. The diagnosis therefore had to be independently agreed by at least two doctors, including one chest physician. Patients were identified from clinical referrals, and from histological, cytological, and necroscopic reports and death certificates. All death certificates in the district, regardless of age at death, have been examined weekly from January 1990 until the present time in September 1995 , and any with the diagnosis of lung cancer or bronchial carcinoma mentioned have been copied by the District Office and sent to one of the investigators (DE). Details of patients dying outside the district were sent by the Office of the Population and Census Survey (OPCS) to the registrar at the District Office, allowing the investigators to review the notes or contact the general practitioner. The notifications have continued since the end of the 30 month study period which has allowed any person diagnosed within the study period to be included. The data therefore include not just the patients seen by the two local chest physicians but also those seen only by other hospital consultants or general practitioners and those diagnosed at necroscopy. Information collected included age at the time of diagnosis, sex, date of diagnosis, initial and subsequent symptoms and signs, initial Eastern Cooperative Oncology Group (ECOG) performance scale 0-4, chest radiographic appearance, results of investigations, histological type of the tumour (if obtained), initial and follow up treatment, and date of death.

All patients with lung cancer over a 30 month period starting from January 1990 (excluding mesothelioma and carcinoid tumours) have been studied in three age groups: under 65 years, 65-74 years, and over 75 years. The following data were analysed: ECOG score at presentation, histological type subdivided into three groups (non-small cell lung cancer (NSCLC), small cell lung cancer (SCLC), and an unknown histology group), whether the patient was reviewed by a chest physician during their illness, and the proportion of each subgroup allocated to a particular treatment modality (surgery, chemotherapy, radiotherapy, or supportive treatment alone) during the first two months after the diagnosis had been established. Radical and palliative radiotherapy
Table 1 Incidence of lung cancer in the Southend district according to age group

\begin{tabular}{llcc}
\hline Age group (years) & \multicolumn{3}{l}{$\begin{array}{l}\text { Incidence per } \\
\text { year }\end{array}$} \\
\cline { 2 - 4 } & Men & Women & Overall \\
\hline All ages & 100 & 41 & 69 \\
$75+$ & 751 & 162 & 359 \\
$65-74$ & 388 & 120 & 238 \\
$55-64$ & NC & NC & 81 \\
$45-54$ & NC & NC & 39 \\
\hline
\end{tabular}

$\mathrm{NC}=$ not calculated (numbers too few).

were grouped together and no attempt was made to differentiate between different chemotherapy regimens. Follow up treatment was excluded. The two consultant chest physicians performed the bronchoscopies and held a weekly combined clinic for patients with lung cancer with consultants from the departments of radiotherapy and oncology to discuss treatment options and assess progress for each patient. Incidence was calculated using the Southend Health District mid 1990 population figures provided by the Population Estimates Unit of the OPCS.

The data were analysed using $95 \%$ confidence intervals for proportions, $\chi^{2}$ test for contingency tables, and $\chi^{2}$ tests for trend.

\section{Results}

DEMOGRAPHIC AND CLINICAL FEATURES

There were 563 new cases of lung cancer in the Southend area during the $\mathbf{3 0}$ month study period, of which $392(70 \%)$ were men. The overall mean age was 71 years (range $31-95$ ); $133(24 \%)$ were under 65 years, $190(34 \%)$ were aged $65-74$ years, and $240(43 \%)$ were over 75 years of age. The incidence of lung cancer in the whole population was 69 per 100000 . The age related incidence is shown in table 1.

Although there is no specific age related referral policy in the district, the proportion of patients diagnosed whilst alive but who were not reviewed by a chest physician increased with age. Ten $(7 \cdot 5 \%)$ patients under 65 years of age, $24(13 \%)$ of the $65-74$ years age group, and $52(22 \%)$ of those aged over 75 were not referred to a chest physician ( $\mathrm{p}<0.001, \chi^{2}=$ 14). The mean age of the 86 patients $(15 \%)$ who were not reviewed by a chest physician was 76 years and of patients seen by a chest physician it was 70 years. The doctor responsible for the care of patients not reviewed by chest physicians was: a geriatrician in 49 $(57 \%)$ of cases, an oncologist in $20(23 \%)$, another consultant physician in $11(13 \%)$, and a general practitioner or other hospital consultant in six $(7 \%)$. Many patients were admitted under other doctors as a diagnosis of lung cancer was not initially clear. If they were subsequently reviewed by a chest physician they were included in the chest physician group. Sixteen $(2 \cdot 8 \%)$ additional patients were diagnosed at necropsy only.

There were fewer patients in the ECOG categories 0 and 1 with increasing age ( $p$ $<0.005, \chi^{2}=8.0$; table 2). 
Table 2 Performance scale (ECOG score) at presentation according to age group

\begin{tabular}{llll}
\hline ECOG score & \multicolumn{3}{l}{ Age group (years) } \\
\cline { 2 - 4 } & $<65$ & $65-74$ & $75+$ \\
\hline 0 & $90(69 \%)$ & $108(57 \%)$ & $100(46 \%)$ \\
1 & $15(12 \%)$ & $29(15 \%)$ & $44(20 \%)$ \\
2 & $9(6 \cdot 9 \%)$ & $19(10 \%)$ & $35(16 \%)$ \\
3 & $9(6 \cdot 9 \%)$ & $14(7 \cdot 4 \%)$ & $19(8 \cdot 8 \%)$ \\
4 & $7(5 \cdot 4 \%)$ & $19(10 \%)$ & $18(8 \cdot 3 \%)$ \\
Total evaluable* & 130 of 133 & 189 of 190 & 216 of 240 \\
\hline
\end{tabular}

* Excluding 16 necroscopic diagnoses and 12 patients with insufficient information. ECOG scale: $0=$ fully active, able to carry out all predisease performance without restriction; $1=$ restricted in physically strenuous activity, but ambulatory and able to carry out light physical work; 2 = ambulatory and capable of all self care but unable to carry out any work activities, up and about more than $50 \%$ of waking hours; $3=$ capable of only limited self care, confined to bed or chair more than $50 \%$ of waking hours; $4=$ completely disabled, cannot carry on any self care, totally confined to bed or chair.

The performance status was significantly worse at presentation in the $75+$ age group $(p<0.005$, $\chi^{2}=8 \cdot 0, \chi^{2}$ test for trend).

Table 3 Histological diagnosis of patients with lung cancer and reviewed by a chest physician according to age group (with $95 \%$ confidence intervals)

\begin{tabular}{lllll}
\hline $\begin{array}{l}\text { Age group } \\
\text { (years) }\end{array}$ & $\begin{array}{l}\text { No. of } \\
\text { patients }\end{array}$ & \multicolumn{2}{l}{ Histological diagnosis } & $\begin{array}{l}\text { No histology } \\
\text { obtained }\end{array}$ \\
\cline { 2 - 4 } & NSCLC & SCLC & 9 \\
\hline$<65$ & 120 & 78 & 33 & $7.5 \%$ \\
& & $65 \%$ & $28 \%$ & $(4$ to $14 \%)$ \\
$65-74$ & 160 & 94 & 36 & $19 \%$ \\
& & $59 \%$ & $23 \%$ & $(13$ to $25 \%)$ \\
$75+$ & 181 & 93 & 27 & 61 \\
& & $51 \%$ & $15 \%$ & $34 \%$ \\
Overall & 461 & 265 & 96 & 100 \\
total & & $57 \%$ & $21 \%$ & $22 \%$ \\
\hline
\end{tabular}

NSCLC $=$ non-small cell lung cancer (squamous cell, adenocarcinoma, large cell, anaplastic and malignant cell of uncertain type); SCLC = small cell lung cancer.

1
${ }^{1}$ For patients in whom no histology was obtained and age group $p<0.001, \chi^{2}=30,\left(\chi^{2}\right.$ test for trend).

HISTOLOGICAL CONFIRMATION

Histological confirmation of the diagnosis was achieved in $418(74 \%)$ cases, including 16 cases diagnosed at necropsy. For patients not reviewed by a chest physician there was a lower rate of histological diagnosis $(48 \%, 41$ of 86 patients, $\mathrm{p}<0.001$ ) than in those reviewed by a chest physician $(78 \%, 361$ of 461 cases). Increasing age led to a lower rate of histological confirmation even if patients not reviewed by a chest physician were excluded (table 3 ).
INITIAL TREATMENT

Initial treatment was defined as that decided upon within two months of the diagnosis and consisted of "active" treatment, defined in this study as either chemotherapy, surgery, or radiotherapy, in 276 (49\%) of all cases. Patients not reviewed by a chest physician were less likely to receive "active" treatment (18 of $86(21 \%)$, $\mathrm{p}<0.001)$. Overall there was a strong relationship between age and treatment both for all patients and for those reviewed by a chest physician (table 4).

In patients with SCLC reviewed by a chest physician there was a significant trend for decreasing use of chemotherapy with increasing age (table 5). However, a high proportion of those aged over 75 received radiotherapy so that the percentage of each age group receiving "active" treatment was $67 \%$ or more (table 5 ).

For patients with NSCLC reviewed by a chest physician there was a significant trend towards symptomatic treatment only with increasing age (table 5). The rates of chemotherapy and surgery accounted for most of the differences between the age groups, with the proportion of patients being given radiotherapy varying less. Patients in whom no histological diagnosis had been made were less likely to receive active treatment, with only five of 93 $(5.4 \%)$ of those aged over 75 in this category receiving active treatment (table 4).

The relationship of ECOG score, age group, and "active" treatment rates is shown in table 6. There was a strong trend for decreasing treatment rates with increasing age for patients in ECOG groups 0 and $1 ; 79 \%$ of those aged under 75 with a performance score rating of 0-1 received either surgery, radiotherapy, or chemotherapy compared with only $39 \%$ of patients aged over $75\left(\mathrm{p}<0.001, \chi^{2}=62\right)$.

\section{Discussion}

The Southend Lung Cancer Register attempts to include all patients diagnosed in a geographically well circumscribed health district. The Yorkshire cancer register study also at-

Table 4 Incidence of initial "active" treatment according to whether reviewed by a chest physician, age group and histological type (with 95\% confidence intervals)

\begin{tabular}{|c|c|c|c|c|c|c|c|c|c|}
\hline \multirow[t]{2}{*}{$\begin{array}{l}\text { Histological } \\
\text { group }\end{array}$} & \multicolumn{3}{|c|}{$\begin{array}{l}\text { Patients reviewed } \\
\text { by chest physician }\end{array}$} & \multicolumn{3}{|c|}{$\begin{array}{l}\text { Patients not reviewed } \\
\text { by chest physician }\end{array}$} & \multicolumn{3}{|l|}{ All patients } \\
\hline & $\begin{array}{l}<65 \\
(n=123)\end{array}$ & $\begin{array}{l}65-74 \\
(n=166)\end{array}$ & $\begin{array}{l}75+ \\
(n=188)\end{array}$ & $\begin{array}{l}<65 \\
(n=10)\end{array}$ & $\begin{array}{l}65-74 \\
(n=24)\end{array}$ & $\begin{array}{l}75+ \\
(n=52)\end{array}$ & $\begin{array}{l}<65 \\
(n=133)\end{array}$ & $\begin{array}{l}65-74 \\
(n=190)\end{array}$ & $\begin{array}{l}75+ \\
(n=240)\end{array}$ \\
\hline $\begin{array}{l}\text { SCLC } \\
(\mathrm{n}=107) \\
\text { NSCLC } \\
(\mathrm{n}=295)\end{array}$ & $\begin{array}{l}29 / 33 \\
88 \% \\
60 / 78 \\
77 \%\end{array}$ & $\begin{array}{l}24 / 36 \\
69 \% \\
62 / 94 \\
66 \%\end{array}$ & $\begin{array}{l}21 / 27 \\
78 \% \\
39 / 93 \\
42 \%\end{array}$ & $\begin{array}{l}2 / 2 \\
100 \% \\
3 / 5 \\
60 \%\end{array}$ & $\begin{array}{l}5 / 5 \\
100 \% \\
4 / 9 \\
44 \%\end{array}$ & $\begin{array}{l}1 / 4 \\
25 \% \\
2 / 16 \\
12 \cdot 5 \%\end{array}$ & $\begin{array}{l}31 / 35 \\
89 \% \\
63 / 83^{4} \\
75 \% \\
(65 \text { to } \\
85 \%)\end{array}$ & $\begin{array}{l}29 / 41 \\
71 \% \\
66 / 103^{4} \\
64 \% \\
(55 \text { to } \\
73 \%)\end{array}$ & \multirow{3}{*}{$\begin{array}{l}22 / 31 \\
71 \% \\
41 / 109^{4} \\
38 \% \\
(29 \text { to } \\
47 \%) \\
5 / 93^{3} \\
5 \cdot 4 \% \\
(2 \text { to } 12 \%) \\
68 / 233^{1} \% \\
29 \% \\
(23 \text { to } \\
35 \%)\end{array}$} \\
\hline $\begin{array}{l}\text { No histology } \\
\text { obtained } \\
(\mathrm{n}=145)\end{array}$ & $\begin{array}{r}5 / 9 \\
56 \%\end{array}$ & $\begin{array}{l}14 / 30 \\
47 \%\end{array}$ & $\begin{array}{l}4 / 61 \\
6 \cdot 6 \%\end{array}$ & $0 / 3$ & $0 / 10$ & $\begin{array}{l}1 / 32 \\
3 \cdot 1 \%\end{array}$ & $\begin{array}{r}5 / 12^{3} \\
37 \% \\
(24 \text { to } 5\end{array}$ & $\begin{array}{l}14 / 40^{3} \\
1 \%)^{*}\end{array}$ & \\
\hline $\begin{array}{l}\text { Total active } \\
\text { initial treatment } \\
(n=547)\end{array}$ & $\begin{array}{l}94 / 120^{2} \\
78 \% \\
(71 \text { to } \\
86 \%)\end{array}$ & $\begin{array}{l}100 / 160^{2} \\
63 \% \\
(55 \text { to } \\
70 \%)\end{array}$ & $\begin{array}{l}64 / 181^{2} \\
36 \% \\
(28 \text { to } \\
42 \%)\end{array}$ & $\begin{array}{l}5 / 10 \\
50 \%\end{array}$ & $\begin{array}{l}9 / 24 \\
38 \%\end{array}$ & $\begin{array}{l}4 / 52 \\
7 \cdot 7 \%\end{array}$ & $\begin{array}{l}99 / 130^{1} \\
76 \% \\
(69 \text { to } \\
84 \%)\end{array}$ & $\begin{array}{l}109 / 184^{1} \\
59 \% \\
(52 \text { to } \\
66 \%)\end{array}$ & \\
\hline
\end{tabular}

SCLC $=$ small cell lung cancer; NSCLC $=$ non-small cell lung cancer.

Excludes 16 patients diagnosed at necropsy.

* Pooled data for $<65$ and $65-74$ age groups.

' For difference in active initial treatment between age groups for all patients, $p<0.001, \chi^{2}=80$.

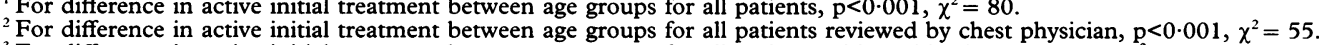

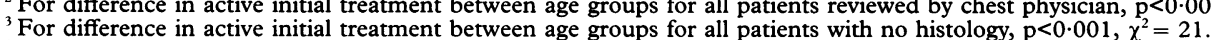

${ }^{4}$ For difference in active initial treatment between age groups for all patients with no histology, $\mathrm{p}<0 \cdot 001, \chi^{2}=21$
${ }^{4}$ For difference in active initial treatment between age groups for all patients with NSCLC, $\mathrm{p}<0 \cdot 001, \chi^{2}=22$. 
Table 5 Type of initial treatment according to age group for patients reviewed by a chest physician

\begin{tabular}{|c|c|c|c|c|c|c|}
\hline \multirow{2}{*}{$\begin{array}{l}\text { Treatment } \\
\text { received }\end{array}$} & \multicolumn{3}{|l|}{$S C L C$} & \multicolumn{3}{|l|}{ NSCLC } \\
\hline & $\begin{array}{l}<65 \\
(n=33)\end{array}$ & $\begin{array}{l}65-74 \\
(n=36)\end{array}$ & $\begin{array}{l}75+ \\
(n=27)\end{array}$ & $\begin{array}{l}<65 \\
(n=78)\end{array}$ & $\begin{array}{l}65-74 \\
(n=94)\end{array}$ & $\begin{array}{l}75+ \\
(n=93)\end{array}$ \\
\hline $\begin{array}{l}\text { Chemotherapy } \\
\text { Surgery } \\
\text { Radiotherapy } \\
\text { Symptomatic } \\
\text { treatment only }\end{array}$ & $\begin{array}{c}26(79 \%)^{1} \\
1(3 \%) \\
2(6 \cdot 1 \%) \\
4(12 \%)\end{array}$ & $\begin{array}{c}23(64 \%)^{1} \\
0 \\
1(2 \cdot 8 \%) \\
12(33 \%)\end{array}$ & $\begin{array}{c}11(41 \%)^{1} \\
0 \\
10(37 \%) \\
6(22 \%)\end{array}$ & $\begin{array}{l}16(21 \%) \\
14(18 \%) \\
30(38 \%) \\
18(23 \%)^{2}\end{array}$ & $\begin{array}{l}6(6 \cdot 4 \%) \\
11(12 \%) \\
45(48 \%) \\
32(34 \%)^{2}\end{array}$ & $\begin{array}{c}0(0 \%) \\
2(2 \cdot 1 \%) \\
37(40 \%) \\
54(58 \%)^{2}\end{array}$ \\
\hline
\end{tabular}

SCLC $=$ small cell lung cancer; NSCLC $=$ non-small cell lung cancer.

Excludes 16 patients diagnosed at necropsy.

${ }^{1}$ For SCLC patients, age group differences for chemotherapy, $\mathrm{p}=0.0026, \chi^{2}=9 \cdot 1\left(\chi^{2}\right.$ test for trend)

${ }^{2}$ For NSCLC, age group differences for symptomatic treatment only, $\mathrm{p}<0.001, \chi^{2}=22\left(\chi^{2}\right.$ test for trend).
Table 6 Proportion of patients given active initial treatment (surgery, chemotherapy, or radiotherapy) according to age group and ECOG performance scale

\begin{tabular}{llll}
\hline ECOG score & \multicolumn{2}{l}{ Age group (years) } \\
\cline { 2 - 4 } & $<65$ & $65-74$ & $75+$ \\
\hline $0-1$ & $90(86 \%)$ & $102(74 \%)$ & $56(39 \%)$ \\
& $(\mathrm{n}=105)$ & $(\mathrm{n}=137)$ & $(\mathrm{n}=144)$ \\
$2-4$ & $11(44 \%)$ & $14(27 \%)$ & $14(19 \%)$ \\
& $(\mathrm{n}=25)$ & $(\mathrm{n}=52)$ & $(\mathrm{n}=72)$ \\
\hline
\end{tabular}

For ECOG $0-1, p<0.001, \chi^{2}=62\left(\chi^{2}\right.$ test for trend).

tempted to include all cases of lung cancer in patients presenting to several towns and different hospitals within a region in the UK. ${ }^{5}$ This is in contrast to other large British, ${ }^{378}$ European, ${ }^{9}$ and American ${ }^{1011}$ series which have only included patients referred to a chest physician, oncologist, or chest surgeon. We believe our study includes virtually all cases of lung cancer because of the multiple sources used to obtain patient data (patient referrals, cytology, histology, necropsies, and death certificates). However, it is possible that a few patients were not identified by our mechanisms, either due to misdiagnosis or referral outside of the district, or due to human error leading to small numbers of patients identified by death certificate or pathological reports not being notified to the investigators. Discrepancy between diagnosis before and after death is commoner in the elderly ${ }^{13}$ and could lead to an underestimate of the number of patients with lung cancer in our oldest age group and a reduction of the age effect on treatment.

We found $43 \%$ of patients with lung cancer were aged 75 years or over, compared with figures of $11-18 \%{ }^{10}$ in the USA and $36 \%$ aged over 70 years in the Edinburgh Lung Cancer Group study. ${ }^{8}$ Consequently, the overall mean age of 71 years is higher than other recent studies $\left(66-68\right.$ years $\left.^{578}\right)$. The proportion of women is also a little higher at $30 \% .{ }^{58}$ Of the population of Southend Health District $8 \cdot 2 \%$ are 75 years or older compared with $7 \%$ for England and Wales, but this does not explain the higher average age. The method of searching a district for cases not normally notified to a chest physician or cancer specialist may possibly have included more elderly frail patients. The Edinburgh Lung Cancer Group ${ }^{8}$ saw approximately $80 \%$ of all new cases within their catchment area and stated that those not seen were "as a group somewhat older and perhaps more frail". Our finding of a higher average age for patients not reviewed by a chest physician supports this view and at least partially explains the high proportion of elderly patients with lung cancer. The rate of histological confirmation in our study is high at $74 \%$ and compares favourably with other series. ${ }^{514}$

We elected to study initial treatment only, to identify patients given an active treatment policy. Follow up treatment would generally be radiotherapy for palliation of symptoms not considered to warrant treatment at the time of diagnosis. Despite the fact that over a quarter of patients aged over 75 years were allocated to one of the "active" treatments, we have clearly shown a large effect of age on treatment decisions with older patients being less likely to receive "active" treatment. The differences are most marked for patients with NSCLC where surgery or chemotherapy were only undertaken in two patients aged over 75 years. There was also a strong trend for decreasing use of chemotherapy for SCLC with increasing age, offset by an increase in the number of patients given radiotherapy.

The possible reasons for different treatment of elderly patients from younger patients are numerous. We have shown that, if no histological diagnosis was made, "active" treatment was less frequently given with only $5 \cdot 4 \%$ of such patients over 75 receiving it. Although we recognise it may be inappropriate to perform invasive procedures in frail patients with a poor prognosis, failure to make a histological diagnosis in the elderly may be one cause of less active treatment. Our study shows that the older patients, as expected, are generally less fit and this is associated with lower treatment rates. However, when divided into groups according to the ECOG scale, there was still a large difference in treatment rates by age for patients in the higher performance categories (table 6). Although this study was confined to one health district, we believe the results are probably representative of other districts within the UK as our overall initial treatment rate of $56 \%$ for patients reviewed by a chest physician is similar to other studies which included follow up treatment. ${ }^{8}$

Advanced age has been proposed as a risk factor for inadequate treatment for patients with cancer, ${ }^{1516}$ and there has been debate on the merits of giving elderly patients as intensive treatment as their younger counterparts. ${ }^{1718} \mathrm{Re}-$ search showing that survival in pneumonia is related to existing medical problems rather than age, ${ }^{19}$ that elderly patients can do well in the intensive care environment, ${ }^{20}$ and evidence that the elderly can tolerate chemotherapy ${ }^{2122}$ and surgery well ${ }^{92324}$ suggest that age alone should not exclude a patient from a particular treatment option.

A histological diagnosis is important in the management of all patients with lung cancer. Each case needs a coherent treatment plan which may involve physicians, surgeons, oncologists, radiotherapists, and palliative care services. This applies to elderly as well as to young patients and we believe that a chest physician is best placed to coordinate this ser- 
vice and that his or her skills should be available to all patients with lung cancer.

The authors wish to thank their colleagues in the departments of oncology, care of the elderly, general medicine, histopathology, and cytology for their help and support in ensuring the accuracy of the lung cancer registry, to Paul Cullinan for his help with designing the database card for the registry, and to Maureen Jones and Margaret Dunmall for their invaluable assistance in the collection of all the data, notes, and radiographs.

1 Office of Population Censuses and Surveys. Mortality statistics: cause, 1991. London: HMSO, Series DH2, no.18: 98-9.

2 Lee-Chiong TL, Matthay RA. Lung cancer in the elderly patient. Clin Chest Med 1993;14:453-78.

3 Le Roux BT. Bronchial carcinoma. Thorax 1968;23:136-43.

4 Davis DL, Lilinfeld AD, Gittelsohn A, Scheckenbach ME. Increasing trends in some cancers in older patients: fact or artifact? Toxicol Ind Health 1986;2:127-44.

5 Connolly CK, Jones WG, Thorogood J, Head C, Muers M.F. Investigation, treatment and prognosis of bronchial carcinoma in the Yorkshire Region

6 Royal College of Physicians. Ensuring equity and quality of care for elderly people. London: The Royal College of Physicians, May 1994.

7 Muers MF, Round CE. Palliation of symptoms in nonsmall cell lung cancer: a study by the Yorkshire Regiona Cancer Organisation thoracic group. Thorax 1993;48:33943.

8 Capewell S. Patients presenting with lung cancer in South East Scotland. Thorax 1987;42:853-7.

9 Mañé JM, Estapé J, Sánchez-Lloret J, Grau JJ, Palombo H, Agusti C, et al. Age and clinical characteristics of 1433 Agusti C, et al. Age and clinical characteristics of 1433

10 O'Rourke MA, Feussner JR, Feigl P, Laszlo J. Age trend of lung cancer stage at diagnosis. Implications for lun cancer screening in the elderly. $\mathcal{F} A M A$ 1987;258:921-6.
11 DeMaria LC Jr, Cohen HJ. Characteristics of lung cancer in elderly patients. F Gerontol 1987;42:540-5.

12 M, Vumings FJ, Glicksman AS, Fretwell MD. Relationship between age at diagnosis and treatment received by cancer patients. $\mathcal{f}$ Am Geriatr Soc 1985;33:585-9.

13 Battle RM, Pathak D, Humble CG, Key CR, Vanatta PR Hill RB, et al. Factors influencing discrepancies between premortem and postmortem diagnoses. $\mathscr{f} A M A 1987 ; 258$ : 339-44.

14 Watkin SW, Hayhurst GK, Green JA. Time trends in the outcome of lung cancer management; a study of 9090 cases diagnosed in the Mersey region, 1974-1986, $B r f$ Cancer 1990;61:590-6.

15 Wetle T. Age as a risk factor for inadequate treatment. FAMA 1987;258:516.

16 Fentiman IS, Tirelli U, Monfardini S, Schneider M, Festen J, Cognetti $\mathrm{F}$ et al. Cancer in the elderly: why so badly treated? Lancet 1990;335:1020-2.

17 Editorial. Do doctors short-change old people? Lancet 1993 ; 342:1-2.

18 Hunt RW, Callahan D. A critique of using age to ration health care and a response. $\mathcal{F}$ Med Ethics 1993;19:19-27.

19 Brancati FL, Chow JW, Wagener MM, Vacarello SJ, Yu VL. Is pneumonia really the old man's friend? Two-yea prognosis after community-acquired pneumonia. Lancet 1993;342:30-3

20 Chelluri L, Pinsky MR, Donahoe MP, Grenvik A. Longerm outcome of critically ill elderly patients requiring intensive care. $\mathcal{F} A M A$ 1993;269:3119-23.

21 Begg CB, Cohen JL, Ellerton J. Are the elderly predisposed to toxicity from cancer chemotherapy?. Cancer Clin Trials 1980;3:369-74

22 Smit EF, Carney DN, Harford P, Sleijfer DT, Postmus PE. A phase II study of oral etoposide in elderly patients with A phase II study of oral etoposide in elderly patients with

for bronchial carcinoma in the elderly. Thorax 1973;28:86-8.

24 Shirakusa $T$, Tsutsui $M$, Iriki N, Matsuba $K$, Saito $T$, Minoda S et al. Results of resection for bronchogenic carcinoma in patients over the age of 80 . Thorax 1989 44:189-91. 